\title{
Singularities of the university spin-off in northern Argentina
}

\author{
Patricia Paola Zachman ${ }^{1}$, Andrés Redchuk ${ }^{2}$ \\ (1) Departamento de Ciencias Básicas y Aplicadas.- Universidad Nacional del Chaco \\ Austral.- Pcia. Roque Sáenz Peña.- Chaco.- Argentina \\ ppz@uncaus.edu.ar \\ (2) Facultad de Ingeniería. Universidad Nacional de Lomas de Zamora.- Buenos \\ Aires.- Argentina. \\ andres.redchuk@gmail.com
}

\begin{abstract}
Summary- In recent decades, argentinian universities, are inserted into the productive environment from creating business incubators university, turned into one of the mechanisms for technology transfer reference. These companies, known as Spin-Off, ideally arise from the knowledge generated within universities. This paper presents a brief summary, the findings of a study of the main characteristics and current status, degree of technological linkage of argentinian universities geographically located in the north, to the conversion of scientific research in business and commercial value.

The information was obtained through semi-structured interviews with a representative sample of spin-off members of accredited at the Ministry of Industry of the Nation and of secondary sources for the analysis of the factors affecting the growth of these companies interviews.

The creation of companies born in the university is a complex phenomenon to study multifactorial reasons for intervening in it. This exploratory study can give some guidance to universities not copy a system, but that adapt best practices to their regional needs, academic infrastructure and economic investments and to obtain optimal results in the creation of technology-based companies.
\end{abstract}

Keywords: university R \& D + i, business incubators of technology-based spin-off, characterization

\section{Introduction}

An important component in the development of university education is the emphasis on the link with the following dimensions: the demands of the laborbusiness-professional market, the requirements of society and the management of human self-realization. The university, the productive sector and regional governments are the main actors in the dynamics of the relationship University - Market - State.

Technology transfer is understood as a process by which technology is loaded through the limits of two entities that may well be countries, companies and even individuals, depending on the viewpoint of the observer or investigator [3]. The aim of the transfer of a particular technology is to allow the receiver to use the technology under the same conditions and with the same benefits as the supplier for its purposes of technological innovation. In fact, talk of a shift implies that there is a consensus 
agreement (license, project incorporation of person between the provider and the recipient of the technology) for this purpose.

With reference to Perez \& Botero [6] technology transfer can be 3 ways: commercial, noncommercial and start-ups; the commercial mode arises between the university and its counterpart either the industry or the state is done through consulting, joint research among others; in the non-commercial way it develops from the university through publications and seminars among others without any commercial interest and contracts and finally the creation of new enterprises with the emergence of the "Spin-Off" mode university.

In the academic literature, Conti et al [1] defines the university spin-off companies that germinate as a university, where a group of researchers make the business unit with a view to the exploitation of knowledge and research results developed in own University. However, it is clear that the phenomena considered as a spin-off are not homogeneous [8]. Thus, companies created by an engineer recently received a researcher who wants to commercially exploit certain results of their research or teacher to rearrange its advisory to industry, are examples of phenomena that are included in the field of spin university off. Therefore, university spin-offs are very heterogeneous phenomena whose borders can vary significantly depending on the perception that they are stakeholders in the field and authors. In the following section different criteria for assessing the diversity of phenomena that contains the concept of university spin-off, concluding with an approach to the characteristics and peculiarities of the Argentine university spin-offs they are identified.

\section{General factors affecting germination and development of the Spin-Off northern Argentina}

For the study of the spin-off the amount of incubators were considered college based in Northern Argentina. A total of 40 incubators registered with the Ministry of Industry accredited by the Access to Credit and Competitiveness, to mention those located in the north (Table 1).

When moving into the issue of Spin-off university, a wide field, heterogeneous, it characterizes him with a variety of concepts used to appoint a fact also diverse, which exemplifies the many approaches you can acquire the establishment of this business is observed. Within our scientific community - technology, the classic profile of the entrepreneur in developed countries is difficult to find. There may be creativity, desires, good projects, but the spirit and businesswoman methodology, known play in the business world, "street", usually is not present. That is denoted by factors such as:

- Entrepreneurial deficit: Scientific institutions usually have not developed a policy to promote entrepreneurship and the characteristics of an entrepreneurial university. There is no social culture related to risk and failure to accept the usual operations Spin-Off type of high commercial risk. From a personal standpoint, for most researchers, creating a business from their knowledge and results is not only far from their interests, but also promoted as an alternative to route a student or professional future graduates. 
- Organizational deficits: The generic function of supporting research, not directly addresses the need or desirability of creating the Spin-Off, although some universities have started pilot programs including incubators and basic support services.

- Deficit experience of the promoter of the idea team: generally the promoters of new ideas with commercial potential have no knowledge and managerial experience. The number of entrepreneurs with business knowledge and strong scientific and technological training, is insufficient to deal with potential ideas in the future should fill the Spin-Off.

- Capital deficit or economic resources: The funding cycle is underdeveloped, with little experience in some of its instruments. There is little tradition in venture capital, lack of investors, and few specialized investors in Spin-Off high risk.

- Sustainability deficit arising from business incubators. Unconsolidated development models involving continuous review and adjustment of the variables of business survival

\begin{tabular}{|l|l|}
\hline \multicolumn{1}{|c|}{ Incubators } & \multicolumn{1}{c|}{ Location } \\
\hline $\begin{array}{l}\text { - Agencia de Desarrollo del Norte Misionero } \\
\text { - UNCUTEL }\end{array}$ & $\begin{array}{l}\text { Puerto Esperanza - Misiones } \\
\text { Parque Tecnológico de El Dorado - } \\
\text { - Parque Tecnológico Misiones }\end{array}$ \\
- UNNETEC - INNOVAR & Misiones \\
- UNCAUS & Corrientes \\
- INTECNOR & Pcia. Roque Sáenz Peña.- Chaco \\
- INCUBA SALTA & Resistencia.- Chaco \\
- Universidad Santo Tomás de Aquino & Salta.- \\
- Facultad de Ciencias Económicas y de Administración. & Tucumán.- \\
Universidad Nacional de Catamarca & Catamarca.- \\
- Centro de Empresarios de Famaillá & Tucumán.- \\
\hline
\end{tabular}

Table 1: Incubators In The Northern Argentina

(MISIONES - CORRIENTES - CHACO - FORMOSA - JUJUY - SALTA - TUCUMAN - SANTIAGO DEL ESTERO CATAMARCA)

Paradoxically, the issue of Spin-Off is not unknown, is quoted as a strategy in many economic development plans or policies on science and technology, not only in countries like Colombia, Peru, Ecuador and Chile; but also as part of Educational Strategic Plans in Argentina. This allows us to infer that there is awareness of the importance which involves the generation of spin-off for economic and technological development of the countries, particularly Argentina, but lack urging members and supporters to achieve satisfactory results [10].

\section{Singularities of the Spin-off}

The diversity of phenomena that occur in the context of university spin-off involves a diversity of characteristics in terms of the realities they cover. Occur, then identified the various characteristics, supported by the literature, which allow the assessment of singularities. 
a) According to the attitude of the university.

- Spin-off spontaneous, passive or pull spin-off: university spin-offs created by members of the university community but have received no support from the university.

- Spin-off planned, active or spin-off push: university spin-offs created under a voluntary support policy carried out by universities, in order to facilitate and promote the transfer of knowledge and entrepreneurial initiatives its members [7].

b) According to the status of people that have given rise to the idea.

- Spin-off academic: university spin-offs created by one or more members of the scientific community, or even people outside the university community, in order to commercially exploit a part of the knowledge developed in the framework of its research. Within this group it is included teachers, assistants, researchers, doctoral students, etc.

- Spin-off of students: university spin-offs created by students at the end of his university studies, have decided to form his own company intends to use a portion of their knowledge by way of the provision of services or through activities production in order to exploit a business opportunity in sectors with generally weak barriers to entry and low technological component. Within this group are observed current or former students of degree or continuing education, which are called start-up.

c) As if the researcher becomes an entrepreneur.

- Spin-off promoted by the researcher, academic spin-off created by one or more members of the university scientific community in order to commercially exploit a part of the knowledge developed in the framework of the research activities of the university.

- Spin-off promoted by foreign entrepreneurs: academic spin-off created by people outside the university scientific community in order to commercially exploit a part of the knowledge developed in the framework of its research activities [9].

In the same vein, whichever is the role taken by the researcher who is at the origin of the idea, are distinguished:

- Spin-off Orthodox: academic spin-off in which a transfer to the new company produces both technology and the inventor.

- Spin-off hybrid: academic spin-off in which a transfer to the new company knowledge is produced, but the inventor remains in college, but somehow participates in the scientific advice to the company.

- Spin-off technology: academic spin-off in which a transfer of knowledge to the new company occurs, but the inventor remains in college and maintains no connection with it.

Also in this line, depending on who carried out the greatest efforts for the spin-off is established, are distinguished:

- Spin-off led by the inventor: academic spin-off in which the effort for its creation is conducted by the inventors of the technology that exploit. 
- Spin-off led by a buyer: spin-off academic in which the effort for its creation is carried out by external entrepreneurs interested in creating companies to exploit university inventions through a license granted by the technology transfer unit of the University.

- Spin-off directed by an investor: spin-off academic in which the effort for its creation is held by investors, typically private equity risk, interested in creating companies to exploit university inventions through a license granted by the technology transfer unit of the university and seeking, then an entrepreneur who is responsible for its creation.

d) Depending on whether proprietary knowledge is transferred.

- Spin-off based on patented technology: university spin-offs are created to exploit the licensed technology patented by the university [4].

- Spin-off based on non-proprietary technology: university spin-offs to exploit knowledge created not patented by the university, usually more generic or may be based on expertise or know-how.

The university spin-off based on codified knowledge and, where appropriate, patented often geared to offer a product to market, while based on tacit knowledge are often geared to providing a service. This different orientation is important because the profile of the university spin-off vary considerably in terms of activities, management of intellectual property rights, financial needs for the development of prototypes, resources required, growth prospects and relations with the university. Thus, academic spin-off based more on codified knowledge develop an industrial manufacturing and selling products or technology development and sales. They are directed from its beginnings to regional markets with high growth potential. The academic spin-off based on tacit knowledge preferably develop a consulting activity. Target regional or national markets, given the importance of customer proximity for good service delivery. Knowledge based on the spin-off is often developed by a single investigator.

e) According to minority participation in the capital of the spin-off.

- Spin-off with foreign capital: academic spin-off received in its initial stage financing of large companies, business angels or venture capital entities.

- Spin-off without foreign capital: academic spin-off that do not receive funding at an early stage of large companies or venture capital entities.

Although financial support of venture capital institutions is possible and desirable because they add credibility, management experience and network of relationships, in practice are insufficient and therefore impact on a small number of spin-off [5]. An alternative is resorting to financing through venture capital is looking for an industrial partner or private investors.

f) Depending on the type of activity.

- Consulting and research services: academic spin-off exploiting core competencies of researchers through an extension of its research activities. 
- Product: academic spin-off created around the concept of products or processes, which are responsible for developing, producing and marketing. These spin-off correspond to the classic entrepreneurial model.

- Technological assets: academic spin-off created to develop technologies that will later be marketed through different mechanisms. Its business model is based on the creation, development and management of technology assets.

- Software: has some common features with the previous case, as the software product often results in licensing agreements, but differs from the previous in that often include a software production process, since in this case are low economies scale.

g) Depending on the model of development followed by the spin-off.

- Growth-oriented academic spin-off seeking a global market for technology. They are characterized by strong capitalization, and participate in capital specialized external institutions. They have highly professional management teams, have strong focus on growth and its ultimate goal is making profits through dividends ..

- No growth-oriented: academic spin-off seeking sufficient to sustain a comfortable life of the founder and his family market. They are characterized by low capitalization, the capital in the hands of the founder environment, low management capacity, little or no focus on growth and its ultimate goal is survival.

Given the foregoing, it can be said that the phenomenon of spin-off covers a wide casuistry and the limits of the concept of spin-off are diffuse [2].

The study of the spin-off of northern Argentina has been made considering the following criteria: a) Cover the largest possible number of common phenomena, b) Establish what attributes or behavior patterns that distinguish according to the local context are.

\section{Conclusions and Discussion}

Some factors in creating company are consistent with common points: The promotion of entrepreneurial culture, patent protection, conflicts of interest regarding royalties and contracts, all of these are completely solved with government regulations science and Technology; The maturation time of their companies have averaged five years, contracts management solution is well established, the financing offered is through seed capital, EMPRETEC Foundation, Fondapymes, Venture Capital, among others. Another point in common is the support offered among which courses, infrastructure, business plan, academic downloads, etc.

Also, small differences are related to each college has its own system of entrepreneurship appropriate to their regional needs, academic infrastructure and economic investments and technological base.

Although the information collected is still insufficient, the first statements about the Spin-Off University can be summarized as follows: 
1) The leading role of the University in creating spin-off based on the current growth and local economies, but the low comparative reference models for the development of these companies,

2) The importance of policies to stimulate entrepreneurship in the University as a tool for conversion of scientific research in business and commercial value,

3) The relative terminological imprecision in the use of the Spin-Off concept, especially in the academic as well as poor dissemination for clarity on all issues related to technology transfer.

4) The incipient development of strategies and logistical entrepreneurially planned medium and long term, with regard to transfer market research methods: determining the size of the market, agree the contribution that generate customer, define the capacity to meet the market, obtaining financial resources, among others. This situation does not promote the organization to plan a draft Spin-Off focused I+D+I, with difficulties to timely warn the market needs and demand relationship - offer.

This research intended to be addressed in the future to a deeper comparison between universities to encourage the creation of companies based on knowledge, where knowledge transfer to the productive sector to provide competitive advantage to countries that are committed to the generation and transfer of knowledge and university technology.

\section{Bibliographic references}

[1] Conti G., G. M., Piccaluga A., La gestione del trasferimento tecnologico. Strategie, Modelli e Strumenti. Springer, Milano, 2011

[2] Garmendia JM \& Castellano A, Tipología de las spin-off en un contexto universitario: una propuesta de clasificación, Cuadernos de Gestión Vol. 12 - N. ${ }^{\circ}$ 1, pp. 39-57, 2011

[3] R. González, V. V., Clemenza, C., \& Ferrer, J. (2007). Vinculación universidadsector productivo a través del proceso de transferencia tecnológica. (Spanish). University-Productive Sector Connections Through the Process of Technological Transfer. (English), 9(2), 267. Rubiralta, M. 2007.

[4] Grandi, A. Y Grimaldi, R., Academics' organizational characteristics and the generation of successful business ideas, Journal of Business Venturing, Vol. 20, $\mathrm{n}^{\circ}$ 6, pp. 821-845, 2005

[5] Heirman, A. Y Clarysse, B. How and Why do Research-Based Start-Ups Differ at Founding? A Resource-Based Configurational Perspective, Journal of Technology Transfer,Vol. 29, n ${ }^{\circ} 3-4$, pp. 247-268, 2004

[6] Pérez, J. E. A., \& Botero, C. A. A. Transferencia de conocimiento orientada a la innovación social en la relación ciencia-tecnología y sociedad. (Spanish). Pensamiento \& Gestión, pp .137-166, 2011.

[7] Pirnay, F.; Surlemont, B. Y Nlemvo, F.: Toward a Typology of University Spinoff, Small Business Economics, $n^{\circ}$ 21, pp. 355-369, 2003

[8] REDVITEC 2011. Red VITEC : experiencias de innovación e inclusión UNR Editora. Editorial de la Universidad Nacional de Rosario, 2011. 
[9] Stankiewicz, R. Spin-off companies from universities, Science and Public Policy, Vol. 21, nº 2, pp. 99-107, 1994

[10] Zachman P, Lopez W \& Redchuk A., Abordaje de Spin off universitario desde BPM y SOA pertinentes con el Desarrollo Local. SIIAN 2014. 2do Seminario Internacional para la Investigación en Administración y Negocios, Puerto Vallarta, México. 2014 